\title{
ХIMIYHI TEXНОЛОГIÏ
}

УДК 661.185.76

DOI https://doi.org/10.32838/2663-5941/2019.3-2/07

Луценко Л.С.

Національний університет харчових технологій

Радзісвська I.Г.

Національний університет харчових технологій

Бабенко В.I.

Національний університет харчових технологій

\section{ДОСЛІДЖЕННЯ СТАБІЛЬНОСТІ КОСМЕТИЧНИХ ЕМУЛЬСІЙ ІЗ ВИКОРИСТАННЯМ ГІДРОФІЛЬНОГО ЕМУЛЬГАТОРА}

Розглянуто властивості емульгаторів, приділено увагу їхньому хімічному складу і факторинговим компаніям стабілізації косметичних емульсій. Доведено ефективність використання композиції з двох поверхнево-активних речовин для забезпечення агрегативної $і$ седиментаційної стійкості косметичної емульсії. Встановлено, щзо за мінімального вмісту жирової фази 6\% $і$ за умови введення 2\% гідрофільного емульгатора Olive-emuls i 3,5\% иетеарилового спирту існує можливість отримання косметичного емульсійного засобу з високими сенсорними властивостями. Косметичні засоби, виготовлені із застосуванням розробленої бази, не створюють відчуття жирності, липкості, легкі в нанесенні, швидко розподіляються по поверхні шкіри і всмоктуються.

Ключові слова: технологія, косметика, емульсійний крем, загущувач, цетеариловий спирт.

Постановка проблеми. Емульсії є одними 3 найпоширеніших видів косметичної продукції. Емульсії є основою для різних кремів, косметичного молочка, бальзамів, кремів-фарб для волосся, вітамінних комплексів. Таке різноманіття емульсійних форм зумовлено їхніми специфічними властивостями, зокрема, унікальною можливістю поєднання в собі жирової і водної фази. Діаметральний склад емульсії дає можливість введення різних активних компонентів та зумовлює високі споживчі властивості - поглинання, розподілення по шкірі, зволожуючу здатність тощо.

У косметичній промисловості пред'являються певні вимоги до емульсійних композицій, зокрема, до їх стабільності. Для практичних цілей необхідно вибрати поверхнево-активні речовини (ПАР), що зумовлюють потрібну стійкість емульсії і стабілізують певну кількість дисперсної фази. Слід також визначити, в яких концентраційних межах дана ПАР є стабілізатором. Таким чином, отримання кінцевого продукту з заданими характеристиками базується на експериментальному підході, тобто на проведенні великої кількості попередніх пробних дослідів і виборі кращого складу.
Розробники косметичних засобів повинні мати можливість отримувати композиції із заданим складом, що забезпечує функціональне призначення коштів i бажаний споживчий вигляд. Сьогодні дані про поведінку косметичних емульсій під час введення різних ПАР і високомолекулярних сполук практично відсутні. Це пов'язано як з тим, що склади косметичних композицій підбираються емпірично і $є$ комерційною таємницею кожної компанії, так і $з$ тим, що використовувані ПАР і високомолекулярні сполуки часто є сумішевими системами, а не індивідуальними речовинами, що ускладнює інтерпретацію одержуваних розробниками даних. Однією 3 основних проблем, 3 якими стикаються технологи під час розробки нових рецептур, $є$ проблема стійкості емульсійного косметичного засобу за умови зниженого вмісту жирової фази, що визначається собівартістю кінцевого продукту.

Використання готових емульсійних основ дозволяє значно спростити процес розробки рецептур косметичних засобів. Готові емульсійні бази повинні володіти високими тактильними властивостями, загальноприйнятим товарним виглядом за одночасної умови економічності їхнього виробництва. 
Аналіз останніх досліджень і публікацій. В косметичній промисловості поверхнево-активні речовини для стабілізації косметичних засобів емульсійного типу називають емульгаторами [1, с. 178].

С достатня кількість ПАР самих різних класів 3 приблизно однаковою емульгуючою здатністю. Однак під час вибору їх слід враховувати фізико-хімічні властивості всієї системи і область застосування емульсії. Так, в кислому середовищі повинні застосовуватися катіоноактивні емульгатори, а в лужному - аніоноактівні. Якщо в полярній фазі присутня значна кількість солей, то краще використовувати неіоногенні емульгатори, як і при коливаннях $\mathrm{pH}$ середовища [2, с. 22].

Дуже часто для стабілізації емульсій використовують суміші ПАР. Зазвичай можливість регулювання властивостей емульсій, зокрема, підвищення ïx стійкості, в такому випадку є значно ширшим порівняно з індивідуальними ПАР. Це пояснюється міжмолекулярною (асоціативною) взаємодією ПАР на міжфазній межі з утворенням більш щільної і впорядкованої упаковки молекул на поверхні [3, с. 428]. Найбільш ефективними змішаними стабілізаторами є суміші іоногенних і неіоногенних ПАР, причому найчастіше використовуються суміші аніонних і неіоногенних ПАР [4, с. 29].

В роботі Л.І. Перегудової [5, с. 1169] було показано, що суміш іоногенного ПАР (алкілбензолсульфоната натрію) і неионогенного ПАР (проксанол-228) більш поверхнево-активна, ніж кожна 3 досліджених ПАР. У присутності суміші ПАР на міжфазному кордоні утворюється змішаний адсорбційний шар, що призводить до збільшення спорідненості міжфазного шару до суміжних фаз. В роботі С.Е. Мухтарової [6, с. 143] зазначено, що введення допоміжних спів-ПАР супроводжується збільшенням адсорбції основного ПАР і зниженням міжфазного натягу. Опубліковані роботи, що стосуються стабілізації емульсій сумішами високомолекулярних і низькомолекулярних ПАР [7-9], кілька робіт присвячено стабілізації емульсій сумішами ПАР і протеїнів $[10,11]$.

Формулювання цілей статті В роботі проаналізовано емульгатор для прямих емульсій Oliveemuls (INCI: Cetearyl glucoside) та цетеариловий спирт (INCI: Cetearyl Alcohol), що проявляе властивості співемульгатора 3 метою виявлення межі їх емульгуючої здатності. Незважаючи на те, що дані ПАР є сполуками, що випускаються в промислових масштабах, їх колоїдно-хімічні характеристики у відкритій літературі відсутні. Знання цих характеристик необхідне для обгрунтованого підходу під час розробки рецептур на їхній основі, тому доцільним виявляється експериментальне їх визначення.

Виклад основного матеріалу. 3 метою виявлення мінімальної межі емульгуючої здатності емульгатора Olive-emuls було виготовлено емульсії, в яких співвідношення водної та жирової фаз не змінювались $(2,5: 1)$, а емульгатор додавався у кількості $1,1,5,2,2,5$ та $3 \%$.

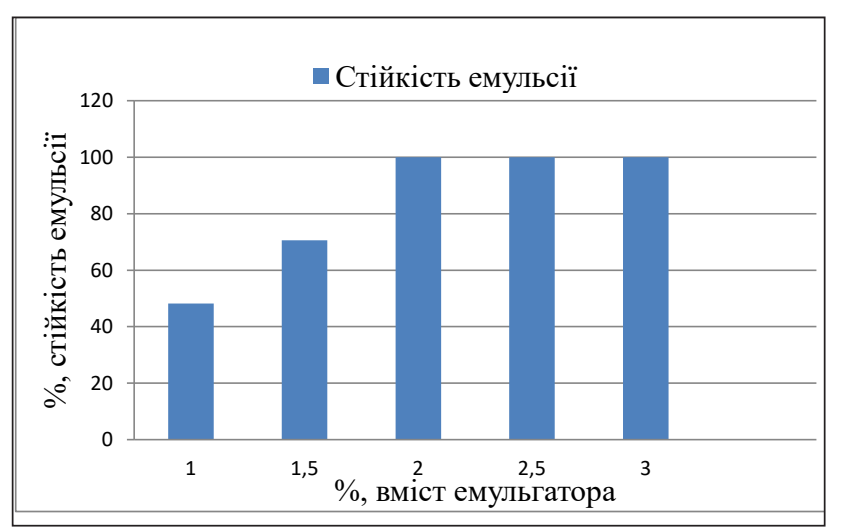

Рис. 1. Залежність стійкості емульсії від вмісту емульгатора

3 рис. 1 видно, що при введенні 2\% емульгатора стійкість емульсії досягає $100 \%$ і не змінюється за наступного його збільшення. Таким чином, під час виготовлення прямих емульсій доцільно вводити емульгатор в кількості 2\%, що дозволяє отримувати стійкі системи. Однак з точки зору реології їхні властивості $є$ незадовільними: такі системи дуже малов'язкі, що для технології косметичних продуктів недопустимо. Вирішити зазначені проблеми дозволяє введення так званих структуроутворювачів, в якості яких в даній роботі використовується цетеариловий спирт.

Цетеариловий спирт являє собою речовину, що не розчинна у воді, обмежено розчинна в олії. Для визначення межі розчинності в олії була приготовлена серія розчинів структуроутворювача різної концентрації.

Таблиця 1

\section{Визначення межі розчинності цетеарилового спирту в олії}

\begin{tabular}{|c|c|}
\hline $\begin{array}{c}\text { Концентрація розчинів } \\
\text { цетеарилового спирту, \% }\end{array}$ & $\begin{array}{c}\text { В'язкість розчинів } \\
\text { цетеарилового спирту, Па·с }\end{array}$ \\
\hline 0 & 1,011 \\
\hline 0,5 & 1,247 \\
\hline 1,0 & 1,370 \\
\hline 2,0 & 1,560 \\
\hline 3,0 & 2,184 \\
\hline 4,0 & 4,050 \\
\hline
\end{tabular}


Виявлено, що до 3,0\% мас. цетеариловий спирт повністю розчиняється в олії, а перевищення концентрації призводить до помутніння розчинів. 3 огляду на той факт, що приготування емульсії здійснюється під час нагрівання до $70^{\circ}$, було досліджено поведінку реології розчинів структуроутворювача за підвищеної температури.

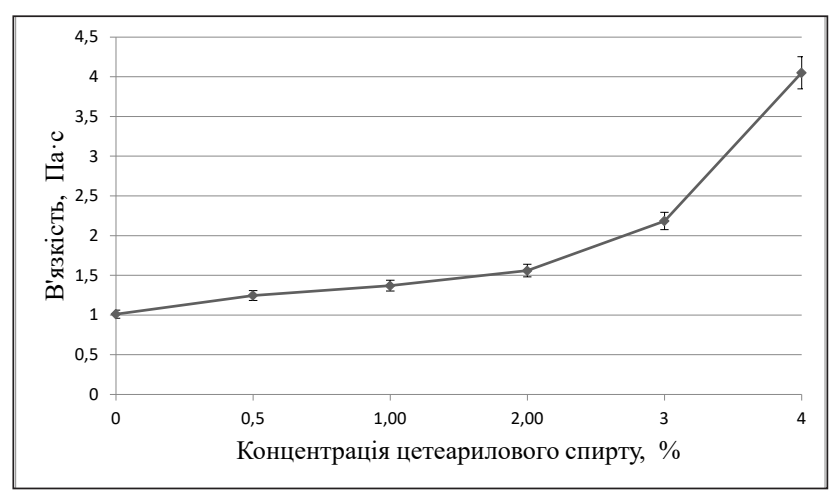

Рис. 2. В'язкість розчинів цетеарилового спирту в олії

Таким чином, проведені дослідження вказують, що в інтервалі концентрацій 2,2-3,5\% мас. в розчинах цетеарилового спирту протікають процеси асоціації. Для подальших досліджень була обрана концентрація структуроутворювача 3,5\% мас., тобто така концентрація, за якої його розчини проявляють псевдопластичну поведінку. Встановлено, що введення до складу жирової фази емульсії 3,5\% цетеарилового спирту дозволяє одержати засоби 3 високими сенсорними властивостями: без відчуття жирності, липкості, легкі в нанесенні, що швидко розподіляються по поверхні шкіри і всмоктуються.

Стабільність косметичних емульсій залежить не тільки від вмісту емульгатора, але і від кількості жирової фази. В косметичних емульсійних композиціях вміст жирових фаз варіюється зазвичай в межах 1-20\% об. залежно від виду продукції крем, молочко і так далі. Співвідношення в складі косметики жирової і водної фаз та їх комбінація обирається виробником залежно від конкретних завдань і типу косметики. Необхідно зазначити, що за відсутності структуроутворювача емульсія вкрай нестійка і піддається фазовим розшаруванням протягом 5-10 хвилин.

Встановлено мінімальний вміст жирової фази, що забезпечує одержання стійкої емульсії. Критерієм стійкості емульсій $є$ час розшарування композиції, добре помітний візуально.

На кривій рис. 3 спостерігається максимум, що відповідає концентрації жирової фази від 6 до 8\%, коли час життя емульсії максимальний.

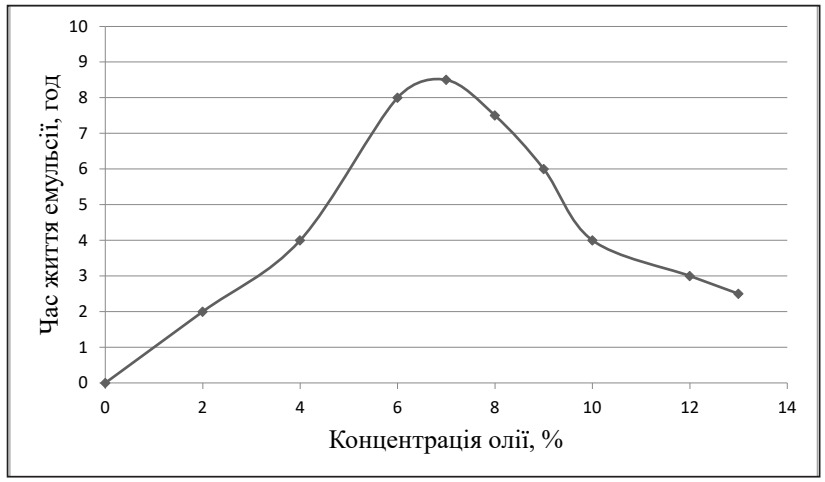

Рис. 3. Залежність часу життя емульсії від концентрації олії

Крива описує поведінку емульсії з використанням 2\% емульгатора Olive-emuls. При цьому, згідно з нормативною документацією, мінімально допустимий рівень в'язкості відповідає емульсії, що містить 5-6\% мас. жирової фази, тому подальші дослідження проводилися за концентрації олії $6 \%$.

Проведені попередні дослідження дозволяють сформулювати склад емульсійної основи косметичного крему (табл. 2).

Таблиця 2

\section{Склад емульсійної основи косметичного крему}

\begin{tabular}{|c|c|c|c|}
\hline \multicolumn{2}{|c|}{ Найменування компонентів } & \multirow[b]{2}{*}{ Властивості } & \multirow{2}{*}{$\begin{array}{l}\text { Норма } \\
\text { вне- } \\
\text { сення, } \\
\text { мас. \% }\end{array}$} \\
\hline Тривіальне & Номенклатурне & & \\
\hline \multicolumn{4}{|c|}{ Жирова фаза } \\
\hline $\begin{array}{c}\text { Олія } \\
\text { косметична }\end{array}$ & Butter & емолент & 6,0 \\
\hline $\begin{array}{c}\text { Спирт цетеа- } \\
\text { риловий }\end{array}$ & Cetearyl alcohol & $\begin{array}{c}\text { модифікатор } \\
\text { реології }\end{array}$ & 3,5 \\
\hline \multicolumn{4}{|c|}{ Водна фаза } \\
\hline $\begin{array}{l}\text { Емульгатор } \\
\text { Olive-emuls }\end{array}$ & $\begin{array}{c}\text { Cetearyl } \\
\text { Glucoside }\end{array}$ & $\begin{array}{c}\text { моноемуль- } \\
\text { гатор прямих } \\
\text { емульсій }\end{array}$ & 2,0 \\
\hline $\begin{array}{c}\text { Вода деміне- } \\
\text { ралізована }\end{array}$ & $\begin{array}{c}\text { Оксид гідро- } \\
\text { гену, вода }\end{array}$ & розчинник & решта \\
\hline
\end{tabular}

Використання запропонованої емульсійної основи дозволяє одержати засоби з високими сенсорними властивостями: без відчуття жирності, липкості, легкі в нанесенні, що швидко розподіляються по поверхні шкіри і всмоктуються. Одержана емульсія характеризується наступними органолептичними показниками:

- зовнішній вигляд - однорідна кремо-подібна маса без сторонніх домішок;

- колір - білий; 
- запах - нейтральний, невиражений, без сторонніх запахів;

- тактильні відчуття - в'язка, гладка і ніжна однорідна маса, приємна під час нанесення на шкіру.

Висновки. Досліджено вплав гідрофільного емульгатора Olive-emuls на стабільність емульсії типу о/в і встановлено, що введення $2 \%$ емульгатора забезпечує колоїдну стабільність системи. Встановлено оптимальну концентрацію цетеарилового спирту, як загущувача жирової фази, що становить $3,5 \%$ мас. за показником в'язкості водно-жирової емульсії з вмістом олії 6\%. Виго- товлені за розробленою рецептурою зразки відповідали стандартному рівню якості та мали сумарну стійкість не менше $100 \%$.

За результатом проведених досліджень, розроблено рецептуру основи косметичної емульсії 3 новим складом інгредієнтів, що може бути використана як база для різних косметичних продуктів, зокрема, косметичного молочка, бальзаму, крему. Технічним результатом розробки є можливість отримання готового продукту з однорідною кремо-подібною консистенцією з загальноприйнятим товарним виглядом, що добре розподіляється по поверхні шкіри.

\section{Список літератури:}

1. Єфімова В.Г., Пилипенко Т.М., Невпряга П.Ю. Розробка рецептури емульсійного косметичного продукту на основі колоїдних закономірностей. Технічні науки та технологіï. 2018. № 1 (11). С. 178-187.

2. Чудинова Н.Н. Синтез и коллоидно-химические характеристики косметических эмульсий, стабилизированных ПАВ : дис. ... канд. хим. Наук : 02.00.11. Москва, 2014. 133 с.

3. Мчедлов-Петросян М.О., Лебідь В.І., Глазкова О.М., Лебідь О.В. Колоїдна хімія / за ред. М.О. Мчедлова-Петросяна. Харків : ХНУ ім. В.Н. Каразіна, 2012. 500 с.

4. Волювач О.В. Аналіз поведінки іоногенних поверхнево-активних речовин і поліетиленгліколю-1500 на межі поділу фаз водний розчин-повітря. URL: http://ekmair.ukma.edu.ua/handle/123456789/1881 (дата звернення: 16.05.2019)

5. Перегудова Л.И., Урьев Н.Б. Коллоидно-химические свойства смеси поверхностно-активных веществ. Коллоидный журнал. 1984. Т.46. № 6. с. 1166-1171.

6. Мухтарова С.Э. Дисперсность и агрегативная устойчивость косметических эмульсий, стабилизированных стеаратными мылами : дис. ... канд. хим. Наук : 02.00.11. Москва, 2003. 153 с.

7. Деркач С.Р., Левачев С.М., Кукушкина А.Н. и др. Вязкоупругость концентрированных эмульсий, стабилизированных бычьим сывороточным альбумином в присутствии неионного ПАВ. Коллоидный журнал. 2007. Т. 69. № 2. с. 170-177.

8. Измайлова В.Н., Деркач С.Р., Зотова К.В. Влияние углеводородных и фторсодержащих поверхностноактивных веществ на свойства желатины в объёме водной фазы и на границе с воздухом. Коллоидный журнал. 1993. Т. 55. № 3. с. 54-90.

9. Измайлова В.Н., Деркач С.Р., Левачев С.М. Влияние додецилсульфата натрия на свойства межфазных адсорбционных слоёв желатины в стабилизированных ею эмульсионных плёнках. Коллоидный журнал. 1997. T. 59. № 2. c. 174-177.

10. Kelley D., McClements D.J. Influence of sodium dodecyl sulfate on the thermal stability of bovine serum albumin stabilized oil-in-water emulsions. Food Hydrocolloids. 2003. № 17. P. 87-93.

11. Dimitrova T.D., Leal-Calderon F. Forces between Emulsion Droplets Stabilized with Tween 20 and Proteins. Langmuir. 1999. № 15. P. 8813-8821.

\section{ИССЛЕДОВАНИЕ СТАБИЛЬНОСТИ КОСМЕТИЧЕСКИХ ЭМУЛЬСИЙ С ИСПОЛЬЗОВАНИЕМ ГИДРОФИЛЬНОГО ЭМУЛЬГАТОРА}

Рассмотрены свойства эмульгаторов, изучен их химический состав и факторы стабилизации косметических эмульсий. Доказана эффективность использования композиции из двух поверхностноактивных веществ для обеспечения агрегативной и седиментационной устойчивости косметической эмульсии. Установлено, что при минимальном содержании жировой фазы 6\% и при введении 2\% гидрофильного эмульгатора Olive-emuls и 3,5\% соемульгатора иетеарилового спирта существует возможность получения косметического эмульсионного средства с высокими сенсорными свойствами. Косметические средства, изготовленные с применением разработанной базы, не создают ощущения жирности, липкости, они легкие в нанесении, быстро распределяются по поверхности кожи и всасываются.

Ключевые слова: технология, косметика, эмульсионный крем, загуститель, иетеариловый спирт. 
INVESTIGATION OF THE STABILITY OF COSMETIC EMULSIONS

USING A HYDROPHILIC EMULSIFIER

The properties of emulsifiers have been considered, the attention has been paid to their chemical composition and factors of stabilization of cosmetic emulsions. The efficiency of using a composition from two surfactants has been proved to provide aggregate and sedimentation stability of a cosmetic emulsion. It has been established that with a minimum content of the fat phase of $6 \%$ and with the introduction of $2 \%$ of the hydrophilic emulsifier Olive-emuls and 3.5\% of the coetemarger of cetearyl alcohol, it is possible to obtain a cosmetic emulsion with high sensory properties. Cosmetic products made using the developed base do not create a feeling of greasiness, sticky, easy to apply and quickly spread on the surface of the skin and absorbed.

Key words: technology, cosmetics, emulsion cream, thickener, cetearyl alcohol. 